\title{
Improvement of mechanical properties and fatigue life by shot peening process on ASTM A516 Grade 70 steel
}

\author{
Mohd Rashdan Isa *, Omar Suliman Zaroog, Kalaikathir Murugan, Sharif Osman Kabashi Guma, \\ Fareg Saeid Ali
}

Department of Mechanical Engineering, Universiti Tenaga Nasional, Jalan Ikram-Uniten, 43000 Kajang, Selangor, Malaysia

Corresponding author: mrashdan@uniten.edu.my

\section{Article history}

Received 27 February 2018

Revised 28 March 2018

Accepted 21 May 2018

Published Online 3 December 2018

\begin{abstract}
ASTM A516 Grade 70 is widely used in the industrial sector as it provides very good mechanical properties in tough conditions. The main usage of this material is in moderate and low operating services. This paper focuses on the effect of shot peening process on ASTM A516 Grade 70 on improving the mechanical properties and fatigue life of the material. Samples have been shot peened with steel shot to induce compressive residual stress. Hardness, tensile and fatigue test as well as microstructure were done on the samples before and after shot peening process to study the effects on mechanical properties. The result shows that there is an increment in every test after shot peening process. There is a slight increment of $0.47 \%$ in hardness value, $0.39 \%$ increment in tensile strength and $6.78 \%$ increment in fatigue life of the material after shot peening process applied. The slight increment in every result was due to the low intensity of the shot peening process. Result also shows that the shot peening process compressed the molecules closer to each other as can be seen under SEM. Therefore it was proven that in this study, there is a very significant improvement in mechanical properties and fatigue life by shot peening process on ASTM A516 Grade 70 Steel.
\end{abstract}

Keywords: Shot peening, hardness, tensile, microstructure, fatigue

\section{INTRODUCTION}

ASTM A516 Grade 70 is widely used in the industrial sector mainly in building with this material as it provides very good mechanical properties in tough conditions. The main usage of this material is in moderate and low operating services. Shot peening process is applied to the material mainly to enhance the performance of the material, hence to increase the fatigue life.

ASTM A516 Grade 70 Steel plate is well-known primarily for service in welded pressure vessels where improved notch toughness brings great significance to the industry (Alias et al., 2013). This material is an excellent choice for service in lower than ambient temperature application, has excellent notch toughness and is used in both pressure vessels and industrial boilers. It offers a greater Yield and Tensile strength when compared to ASTM A516 Grade 65 and can operate in lower temperatures. It's ideally suited for high standard set by the oil, gas and petrochemical industry.

\section{LITERATURE REVIEW}

The mechanical properties of ASTM A516 Grade 70 are referring to the high tensile stress, high hardness and long fatigue life. This paper studies the effect of shot peening process on ASTM A516 Grade 70 on improving the mechanical properties and fatigue life of the material. The study also focuses on the change in the microstructure of the material. Shot peening is a cold performed function (does not comprise any type of hot treatment) where the surface of a substance is blasted with certain round named shot (Morabito, Chrysochoos, Dattoma, \& Galietti, 2007). This process was proven that it can improve the microstructure and mechanical properties of steel as well as adding corrosion resistance (Dieng, Amine, Falaise, \& Chataigner, 2017; Xu, Sheng, Wang, Jiao, \& Yuan, 2017).

The fatigue test is a crack or break which is a permanent structural change that results from fluctuating stress and strain that occurs in materials that happen within a sufficient number of fluctuations. The simultaneous action of cyclic stress, tensile stress, and plastic strain cause fatigue fracturing. The crack could not be propagated if there are no any of those factors present. Fatigue would not happen because of a compressive stress but the compression load will make it happen. The crack is initiated from cyclic stress and the propagation which is the crack growth continued by the tensile stress (Bae, Lee, Pyo, \& Choi, 2016; Kida, Koga, \& Santos, 2017; Martins, Ferreira, Reis, \& Chambel, 2016).

This paper studied the effect of shot peening on enhancing the properties of the ASTM A516 grade 70 steel.

\section{METHODOLOGY/MATERIALS}

\section{Testing Sample Preparation}

The Carbon steel ASTM A516 / SA 516 Grade 70 standard industrial plate were cut using the Computer Numerical Control (CNC) cutting machine in the standard ASME 1989 (Section 9 Code 
QW.462.1) dog bone measurement according to the Tensile and Fatigue test which is the same dimensions for both types of experiment. Figure 1 shows the dimension of the testing sample.

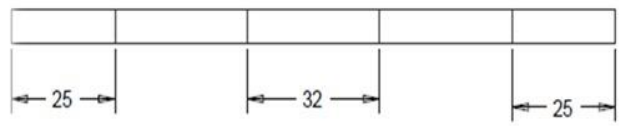
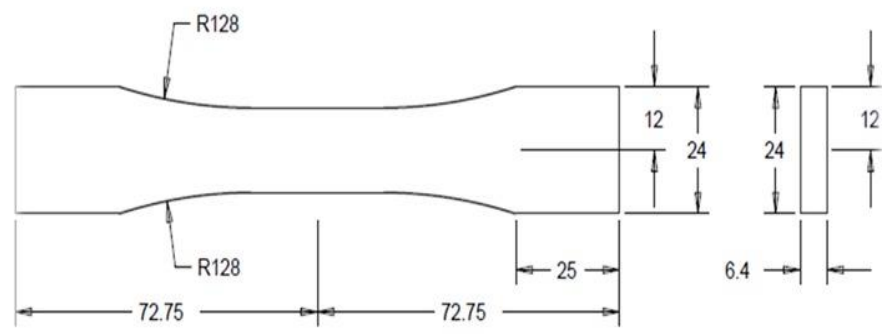

Fig. 1 ASTM A516 Grade 70 testing sample.

\section{Shot peening process}

Shot peening using steel balls with the size of 0.8 to $1.0 \mathrm{~mm}$ was applied on the samples. Table 1 illustrates the detailed parameters of the process.

Table 1 Shot peening parameters.

\begin{tabular}{ccc}
\hline Parameter & Value & Unit \\
\hline Arc height & 0.4 & $\mathrm{~mm}$ \\
Peening coverage & 100 & $\%$ \\
Rotation & $5 \sim 10$ & $\mathrm{Amp}$ \\
Steel shot grade & $\mathrm{S} 330$ & - \\
Steel shot size & $0.8 \sim 1.0$ & $\mathrm{~mm}$ \\
Steel shot hardness & $45 \sim 55$ & HRC \\
Nozzle angle & 37.5 & Degree \\
\hline
\end{tabular}

\section{Mechanical Test}

Mechanical test such as hardness, tensile and microstructure was done on the samples before and after shot peening process to study the effects on mechanical properties. Hardness test was carried out using Rockwell Hardness Tester by taking the measurement on 8 different points on the samples. The measurement was taken by applying indenter under a preliminary minor load of $10 \mathrm{kgf}$ according to ASTM E18 standard. The tensile test was performed on a universal tensile testing machine which could bear up to $50 \mathrm{kN}$ of the load applied and hence the Ultimate Tensile Strength of the material was determined. Fatigue Test was done by applying cyclic loads of $85 \%$ and $75 \%$ of the Ultimate Tensile Strength. The frequency of the test was $10 \sim 15 \mathrm{~Hz}$. Scanning Electron Microscopy (SEM) was performed on the samples after the fracture of tensile and fatigue test using a microscope with the magnification of $1500 x$.

\section{RESULTS AND FINDINGS}

\section{Hardness test}

The result of the hardness test is tabulated as in Table 2. The average value of the hardness after shot peening shows an increment of $0.47 \%$ in comparison of the hardness before shot peening. Based on the literature review, the hardness after shot peening should significantly increase. One of the possible reason that the increment is not so high is due to low shot peening intensity. The higher intensities of the shot peening, the higher hardness of the material.
Table 2 Hardness value of ASTM A516 Grade 70 before and after Shot Peening.

\begin{tabular}{ccc}
\hline $\begin{array}{c}\text { Points of } \\
\text { measurement }\end{array}$ & $\begin{array}{c}\text { Rockwell } \\
\text { Hardness value, } \\
\text { HRB (Before } \\
\text { Shot Peening) }\end{array}$ & $\begin{array}{c}\text { Rockwell } \\
\text { Hardness value, } \\
\text { HRB (After Shot } \\
\text { Peening) }\end{array}$ \\
\hline 1 & 79.6 & 78.2 \\
2 & 80.5 & 82.7 \\
3 & 81.8 & 79.7 \\
4 & 82.2 & 81.1 \\
5 & 81.4 & 80.4 \\
6 & 81.0 & 83.1 \\
7 & 80.6 & 83.4 \\
8 & 80.9 & 82.5 \\
Average & 81.0 & 81.38 \\
\hline
\end{tabular}

\section{Tensile test}

The tensile test result is tabulated as in Table 3. The tensile stress after shot peening is slightly higher than before shot peening. There is an increment of $0.39 \%$ for tensile stress after shot peening. This result reflects the change in hardness as there is an only minor increment in tensile since the intensity of the shot peening process that was performed on the samples was quite low.

Table 3 Tensile stress value of ASTM A516 Grade 70 before and after Shot Peening.

\begin{tabular}{lcc}
\hline \multicolumn{1}{c}{ Property } & $\begin{array}{c}\text { Before Shot } \\
\text { Peening }\end{array}$ & After Shot Peening \\
\hline Tensile stress at & 47544.00 & 47728.67 \\
maximum load (Mpa) & & \\
Maximum load (N) & 464.30 & 466.10 \\
Tensile strain (\%) & 38.21 & 38.10 \\
\hline
\end{tabular}

\section{Fatigue test}

For the fatigue life test, $85 \%$ and $75 \%$ of the Ultimate Tensile Strength (UTS) was taken as the maximum stress for the fluctuating load force to be applied on the all specimens before and after shot peening.

For the samples before shot peening, the $85 \%$ UTS sample failed after 7 hours of the applied cyclic load with a max elongation of 2.433 $\mathrm{mm}$. The $75 \%$ took 9.4 hours with a max elongation of $3.195 \mathrm{~mm}$. For the samples after shot peening, the $85 \%$ UTS sample failed after 7.5 hours of the applied cyclic load with a max elongation of $2.446 \mathrm{~mm}$. The $75 \%$ took 10 hours with a max elongation of $3.212 \mathrm{~mm}$.

Table 4 shows the final result for a number of cycles before and after shot peening samples. The average increment of $6.78 \%$ in a number of cycles before fatigue fracture shown in this test. This proves that the fatigue life of the material was increased by shot peening process. However, the slight increment in the fatigue life is again due to the low intensity of the shot peening process which reflects the result of hardness and tensile test.

Table 4 Number of cycle fatigue test before and after Shot Peening.

\begin{tabular}{cccc}
\hline Samples & $\begin{array}{c}\text { Number of } \\
\text { Cycle Before } \\
\text { SP }\end{array}$ & $\begin{array}{c}\text { Number of } \\
\text { Cycle After } \\
\text { SP }\end{array}$ & Increment \\
\hline $85 \%$ UTS & 252029 & 270032 & $7.14 \%$ \\
$75 \%$ UTS & 338440 & 360005 & $6.37 \%$ \\
\hline
\end{tabular}

\section{SEM}

Based on the microscopic photos of the samples, it could be observed that the molecules of the material after shot peening are closer to each other. This shows that the shot peening process compressed the molecules closer to produce compressive residual stress in the surface of a material. 


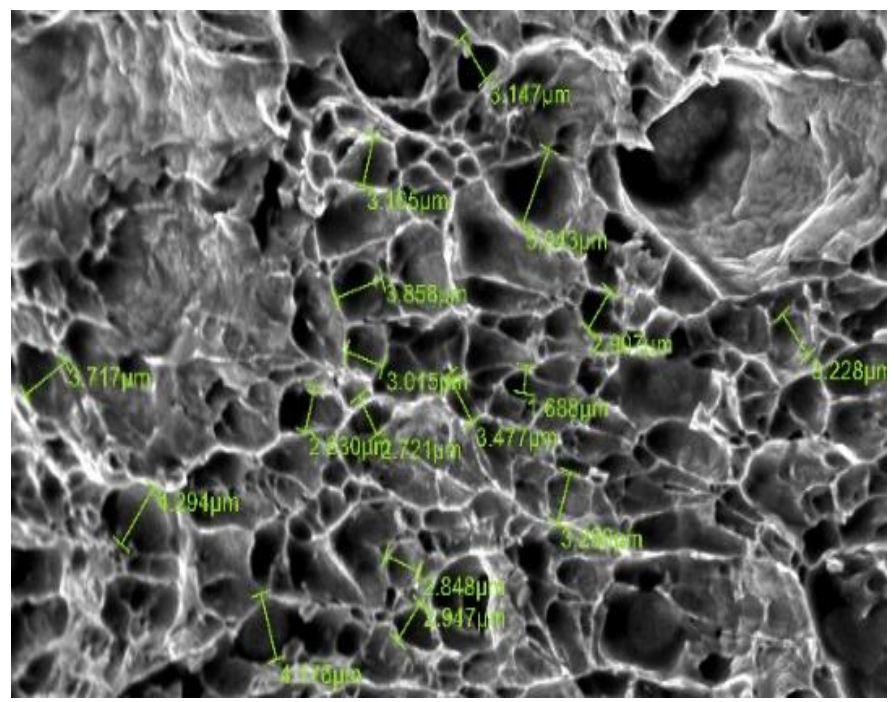

a) SEM before Shot Peening

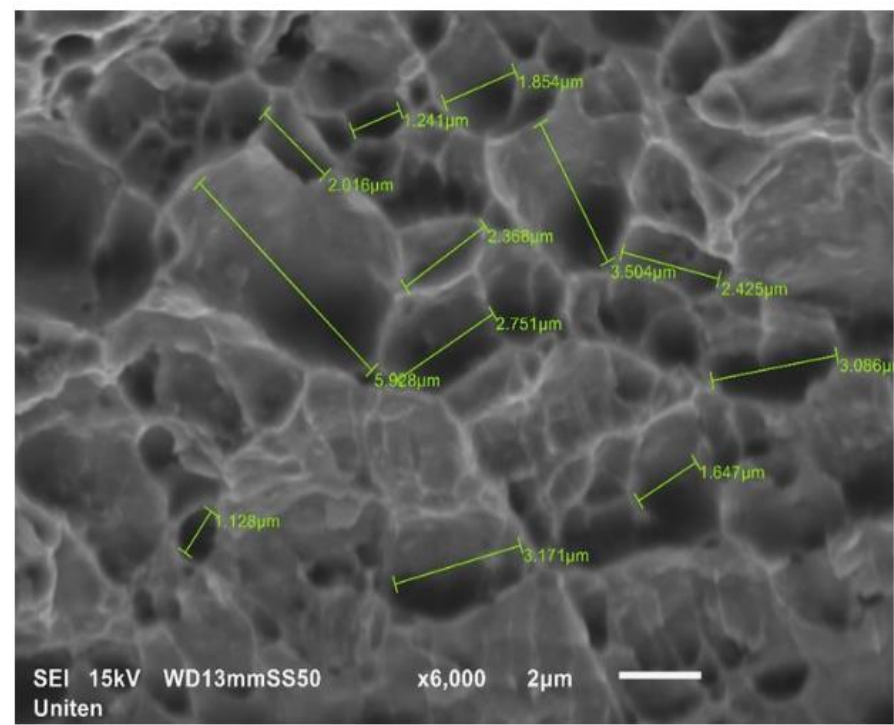

b) SEM after Shot Peening

Fig. 2 Grain size of ASTM A516 Grade 70 microstructure. Tensile fracture before and after shot peening

\section{CONCLUSION}

The compressive residual stress introduced by shot peening affects the mechanical properties of ASTM A516 Grade 70 Steel. This was shown by the result of increment in hardness value, tensile and fatigue life of the material after shot peening process. The slight increment in every result was due to the low intensity of the shot peening process. To have a more significant changing in the result, higher shot peening intensity should be applied to the samples.

\section{ACKNOWLEDGEMENT}

The authors gratefully acknowledge the support provided by the Ministry of High Education Malaysia (MOHE) through the FRGS grant no. FRGS/1/2015/TK03/UNITEN/02/3. The authors also acknowledge the Innovation and Research Management Centre (iRMC) of Universiti Tenaga Nasional (UNITEN).

\section{REFERENCES}

Alias, S. K., Abdullah, B., Jaffar, A., Latip, S. A., Kasolang, S., Izham, M. F., et al. 2013. Mechanical properties of paste carburized ASTM A516 steel. Procedia Engineering, 68, 525-530. doi:http://doi.org/10.1016/ j.proeng.2013. 12.216

Bae, H., Lee, K., Pyo, S., Choi, S. 2016. Abnormality in using cyclic fatigue for ranking static fatigue induced slow crack growth behavior of polyethylene pipe grade resins. Polymer Testing, 55, 101-108. doi:http://doi.org/ 10.1016/ j.polymertesting.2016.07.015

Dieng, L., Amine, D., Falaise, Y., Chataigner, S. 2017. Parametric study of the finite element modeling of shot peening on welded joints. Journal of Constructional Steel Research, 130, 234-247. doi:http://doi.org/10.1016/ j.jcsr.2016.12.018

Kida, K., Koga, J., Santos, E. C. 2017. Crack growth and splitting failure of silicon nitride ceramic balls under cyclic pressure loads. Mechanics of Materials, 106, 58-66. doi:http://doi.org/10.1016/j.mechmat.2017.01.004

Martins, R. F., Ferreira, L., Reis, L., Chambel, P. 2016. Fatigue crack growth under cyclic torsional loading. Theoretical and Applied Fracture Mechanics, 85, Part A, 56-66. doi:http://doi.org/10.1016/ j.tafmec.2016.08.016

Morabito, A. E., Chrysochoos, A., Dattoma, V., Galietti, U. 2007. Analysis of heat sources accompanying the fatigue of $2024 \mathrm{t} 3$ aluminium alloys. International Journal of Fatigue, 29, 5, 977-984. doi:https://doi.org/ 10.1016/ j.ijfatigue.2006.06.015

Xu, C., Sheng, G., Wang, H., Jiao, Y., Yuan, X. 2017. Effect of high energy shot peening on the microstructure and mechanical properties of $\mathrm{mg} / \mathrm{ti}$ joints. Journal of Alloys and Compounds, 695, 1383-1391. doi:http://doi.org/ 10.1016/j.jallcom.2016.10.262. 